\title{
Screening Study on Excretion Pattern of Urinary Glycosaminoglycans from Orthopedic Patients
}

\author{
Katsumi Sato, ${ }^{*}$ Yasuko Nagatsuka, Mamoru Isemura, \\ Noboru Ototani and Zensaku Yosizawa \\ Department of Biochemistry and *Department of Orthopedic \\ Surgery, Tohoku University School of Medicine, Sendai 980
}

\begin{abstract}
Sato, K., Nagatsuka, Y., Isemura, M., Ototani, N. and Yosizawa, Z. Screening Study on Excretion Pattern of Urinary Glycosaminoglycans from Orthopedic Patients. Tohoku J. exp. Med., 1982, 137 (2), 179-190 — To obtain a clue for the metabolic disorder of glycosaminoglycans (GAG) in orthopedic diseases, a screening study on excretion pattern of urinary GAG from orthopedic patients was performed by the procedures of Nagatsuka et al. (1980). All the urines examined gave three regular GAG-bands. Besides the regular bands, some samples gave irregular bands. Of 123 cases examined in the present study, the numbers of cases with an abnormal excretion pattern of urinary GAG in the regular bands (A) and with the irregular band(s) (B) were as follows: 23(A) and $7(\mathrm{~B})$ in 38 cases of rheumatoid arthritis $(\mathrm{RA}) ; 8(\mathrm{~A})$ and $5(\mathrm{~B})$ in 13 cases of malignant bone tumor; $11(\mathrm{~A})$ and $3(\mathrm{~B})$ in 12 cases of benign bone tumor; $16(\mathrm{~A})$ and $3(\mathrm{~B})$ in 25 cases of bone metabolic and connective tissue diseases; $6(\mathrm{~A})$ and $4(\mathrm{~B})$ in 9 cases of osteaorthritis; $6(\mathrm{~A})$ and $3(\mathrm{~B})$ in 8 cases of spine diseases; and $14(\mathrm{~A})$ and $8(\mathrm{~B})$ in 18 cases of other orthopedic diseases. The excretion patterns of urinary GAG suggested that the metabolic rates of chondroitin sulfates tended to elevate in most cases of (A). Also, certain metabolic disorder of dermatan sulfate and heparan sulfate was suggested in several cases of (A). In addition, the abnormal metabolism of acidic glycoprotein(s) was suggested in many cases of (B). Excretion of a large amount of dermatan sulfate was elucidated in one case (Case 20 of bone metabolic and connective tissue diseases) by digestion with chondroitinases after the screening study. Therefore, the metabolic disorder of dermatan sulfate was indicated in this patient. The low activity of $a$-L-iduronidase in her urine supported this indication. This patient was finally diagnosed as mucopolysaccharidosis I-S (Scheie syndrome). - - - glycosaminoglycan; urinary glycosaminoglycans; orthopedic patients
\end{abstract}

To obtain a clue for the metabolic disorder of glycosaminoglycans (GAG) in connective tissue diseases, a device of screening test for excretion pattern of urinary GAG was achieved (Nagatsuka et al. 1980). The results of application of

Received for publication, September 7, 1981.

Abbreviations: GAG, glycosaminoglycans; HexN, hexosamine; UA, hexuronic acid; $\triangle$ Di-0S, 2-acetamido-2-deoxy-3-O-(4-deoxy-o-L-threo-hex-4-enopyranosyluronic acid)-D-galactose; $\triangle \mathrm{Di}-4 \mathrm{~S}$ and $\triangle \mathrm{Di}-6 \mathrm{~S}, 4$-sulfate and 6 -sulfate, respectively, of $\triangle \mathrm{Di}-0 \mathrm{~S}$; RA, rheumatoid arthritis. 
the screening test to normal human urines and to urines from 50 cases of orthopedic patients have been reported (Nagatsuka et al. 1980, 1981).

This paper reports the results of further screening study on excretion pattern of urinary GAG from 123 cases of orthopedic patients.

\section{Materials and Methods}

Urines. Urines were collected separately from 123 cases of orthopedic patients without any dietary restriction as described previously (Nagatsuka et al. 1981). The cases examined are as follows: 38 cases of rheumatoid arthritis (RA); 13 cases of malignant bone tumor; 12 cases of benign bone tumor; 25 cases of bone metabolic and connective tissue diseases; 9 cases of osteoarthritis (arthritis deformans); 8 cases of spine diseases; and 18 cases of other orthopedic diseases.

Materials. Pronase $\mathbf{P}$, Separax (cellulose acetate membrane), Toluidine blue, Alcian blue 8GS, and cetylpyridinium chloride were those described previously (Nagatsuka et al. 1980). Phenyl-c-L-iduronide was purchased from Zeriashinyaku Co., Tokyo. Other materials were commercial products.

Methods. Separation of crude GAG from urine, quantitation of GAG by Separax electrophoresis, quantitation of hexosamine, enzymatic digestion with chondroitinases and heparitinase were performed as described previously (Nagatsuka et al. 1980). Uronic acid was determined by the method of Bitter and Muir (1962). Protein was determined by the procedure of Lowry et al. (1951) using bovine serum albumin as a standard.

Assay for $a$-L-iduronidase. The activity of $a$-L-iduronidase was assayed by the procedure of Liem and Hooghwinkel (1975) as follows: An enzyme solution (250 $\mu \mathrm{l})$ prepared from urine was added to an incubation mixture of $100 \mu \mathrm{l}$ of $5 \mathrm{mM}$ phenyl-cs-Liduronide solution and $25 \mu \mathrm{l}$ of $1.2 \mathrm{M}$ sodium formate buffer ( $\mathrm{pH} 3.5$ ) containing $0.45 \mathrm{M}$ sodium chloride and $0.3 \%$ sodium azide. After incubation for $18 \mathrm{hr}$ at $25^{\circ} \mathrm{C}, 1.25 \mathrm{ml}$ of Folin Ciocalteau phenol reagent was added to the incubation mixture. The mixture was centrifuged, and $1.2 \mathrm{ml}$ of the supernatant was mixed with $0.3 \mathrm{ml}$ of $24 \%$ sodium carbonate. After standing for $20 \mathrm{~min}$ at $37^{\circ} \mathrm{C}$, the absorbance at $660 \mathrm{~nm}$ was read against the blank prepared by the same procedures without substrate. The enzyme activity was expressed as nmole phenol/mg protein $/ 18 \mathrm{hr}$.

\section{Results and Discussion}

All the urines so far examined gave three regular GAG-bands, which were designated as bands 1,2 and 3 , in the order from greatest to least of the electrophoretic mobility, as reported previously (Nagatsuka et al. 1980). However, band 1 often spread over band 2 zone as reported previously (Nagatsuka et al. 1980). In these cases, determination of hexosamine was made as bands $1+2$. Besides the three regular bands, some samples gave irregular bands migrated between band 3 and origin, which were designated as bands 4, 5, 6, 7 and 8 , in the order from greatest to least of the electrophoretic mobility, as reported previously (Nagatsuka et al. 1980). Excretion patterns of urinary GAG, in terms of hexosamine, in these bands were expressed as percent distribution in total. In addition, the amounts of GAG, expressed as $\mathrm{mg} /$ day of hexosamine and hexuronic acid, were also determined.

The components of bands 1,2 and 3 were identified as partially desulfated chondroitin sulfates A and C, dermatan sulfate (major) plus low-sulfated chondroitin sulfates (minor) and heparan sulfate (major) plus low-sulfated chondroitin 
sulfates (minor), respectively, as reported previously (Nagatsuka et al. 1980). Band 4 corresponded to that of hyaluronic acid. Bands 5, 6,7 and 8 were suggested to contain acidic glycoproteins (Nagatsuka et al. 1980).

Excretion pattern of urinary GAG from the patients with $R A$

The cases examined are listed in Table 1. Diagnostic criteria for RA (Ropes

TABLE 1. Excretion pattern of urinary $G A G$ from the patients with rheumatoid arthritis (RA)

\begin{tabular}{|c|c|c|c|c|c|c|c|c|c|c|c|c|}
\hline \multirow[t]{2}{*}{ Case } & \multirow[t]{2}{*}{ Name } & \multirow[t]{2}{*}{ Age } & \multirow[t]{2}{*}{ Sex } & \multirow[t]{2}{*}{ Staige } & \multirow[t]{2}{*}{ Class } & \multirow{2}{*}{$\begin{array}{l}\text { Total GAG } \\
(\operatorname{HexN} / \mathbf{U A})^{*}\end{array}$} & \multicolumn{5}{|c|}{$\begin{array}{l}\text { Distribution of GAG } \\
\text { (as HexN) in bands } \dagger\end{array}$} & \multirow{2}{*}{ Recovery } \\
\hline & & & & & & & 1 & & 2 & 3 & Others & \\
\hline 1 & S.B. & 58 & M & 1 & 2 & $4.63 / 4.44$ & 43 & & 21 & 36 & & 89 \\
\hline 2 & T.S. & 63 & M & 1 & 2 & 4. $30 / 4.19$ & 45 & & 20 & 35 & & 85 \\
\hline 3 & K.T. & 26 & M & 2 & 2 & $6.20 / 5.97$ & & $67 \S$ & & 33 & & 75 \\
\hline 4 & C.S. & 33 & M & 2 & 2 & $4.18 / 4.10$ & 53 & & 19 & 28 & & 95 \\
\hline 5 & K.K. & 44 & M & 2 & 2 & 1. $89 / 1.75$ & 54 & & 15 & 31 & & 100 \\
\hline 6 & T.K. & 61 & M & 2 & 2 & $5.15 / 4.95$ & & 56 & & 44 & & 91 \\
\hline 7 & K.K. & 63 & M & 2 & 2 & 3. $13 / 2.96$ & 69 & & 6 & 25 & & 78 \\
\hline 8 & H.S. & 73 & M & 2 & 2 & $4.58 / 4.00$ & 59 & & 14 & 27 & & 90 \\
\hline 9 & Т.T. & 69 & $\mathrm{~F}$ & 2 & 2 & $7.5 \mathrm{I} / 4.57$ & 49 & & 10 & 22 & $19(5) / /$ & 97 \\
\hline 10 & K.K. & 73 & $\mathrm{~F}$ & 2 & 2 & $2.04 / 2.04$ & 57 & & 17 & 26 & & 90 \\
\hline 11 & T.N. & 62 & M & 3 & 2 & 3. $76 / 3.35$ & 55 & & 15 & 30 & & 96 \\
\hline 12 & S.N. & 67 & M & 3 & 2 & $2.12 / 1.93$ & 56 & & 22 & 22 & & 93 \\
\hline 13 & М.H. & 73 & M & 3 & 2 & $3.15 / 2.98$ & 53 & & 22 & 25 & & 88 \\
\hline 14 & E.A. & 27 & $\mathbf{F}$ & 3 & 2 & $6.09 / 4.32$ & 34 & & 12 & 17 & $\left\{\begin{array}{l}20(5) \\
17(6)\end{array}\right.$ & 80 \\
\hline 15 & E.T. & 29 & $\mathrm{~F}$ & 3 & 2 & 5. 37/3. 09 & 41 & & 15 & 14 & $\left\{\begin{array}{l}20(7) \\
10(8)\end{array}\right.$ & 76 \\
\hline 16 & R.Y. & 38 & $\mathrm{~F}$ & 3 & 2 & $3.44 / 3.23$ & 57 & & 15 & 28 & & 95 \\
\hline 17 & E.H. & 39 & F & 3 & 2 & $3.24 / 2.55$ & 39 & & 15 & 26 & $20(7)$ & 86 \\
\hline 18 & K.H. & 42 & $\mathrm{~F}$ & 3 & 2 & $1.05 / 0.97$ & & 68 & & 32 & & 98 \\
\hline 19 & H.A. & 60 & $\mathbf{F}$ & 3 & 2 & $2.93 / 2.73$ & 62 & & 10 & 28 & & 88 \\
\hline 20 & M.T. & 67 & $\mathrm{~F}$ & 3 & 2 & $1.96 / 1.63$ & 46 & & 23 & 31 & & 84 \\
\hline 21 & T.E. & 70 & $\mathrm{~F}$ & 3 & 2 & 2. $60 / 2.58$ & 52 & & 20 & 28 & & 98 \\
\hline 22 & T.K. & 43 & $\mathrm{~F}$ & 3 & 3 & $2.73 / 2.16$ & 32 & & 24 & 27 & $17(6)$ & 93 \\
\hline 23 & F.K. & 55 & $\mathrm{~F}$ & 3 & 3 & $3.48 / 2.61$ & 56 & & 12 & 19 & $13(5)$ & 82 \\
\hline 24 & R.A. & 57 & $\mathrm{~F}$ & 3 & 3 & $1.86 / 1.44$ & 56 & & 23 & 21 & & 90 \\
\hline 25 & R.G. & 66 & $\mathrm{~F}$ & 3 & 3 & $3.16 / 2.81$ & 39 & & 22 & 39 & & 79 \\
\hline 26 & T.S. & 29 & M & 4 & 2 & 2. $97 / 2.89$ & 56 & & 16 & 28 & & 97 \\
\hline 27 & Y.O. & 50 & M & 4 & 2 & 4. $10 / 3.49$ & 56 & & 14 & 30 & & 84 \\
\hline 28 & K.K. & 27 & $\mathrm{~F}$ & 4 & 3 & $1.58 / 1.41$ & & 61 & & 39 & & 81 \\
\hline 29 & S.N. & 42 & $\mathrm{~F}$ & 4 & 3 & $5.35 / 4.50$ & 45 & & 24 & 31 & & 91 \\
\hline 30 & S.C. & 60 & $\mathrm{~F}$ & 4 & 3 & $2.48 / 2.22$ & & 64 & & 36 & & 86 \\
\hline 31 & F.K. & 65 & $\mathrm{~F}$ & 4 & 3 & $1.99 / 1.53$ & 57 & & 14 & 29 & & 94 \\
\hline 32 & K.S. & 69 & $\mathrm{~F}$ & 4 & 3 & 4. $06 / 3.80$ & 68 & & 10 & 22 & & 72 \\
\hline 33 & K.Y. & 41 & $\mathrm{~F}$ & 4 & 4 & $3.37 / 2.96$ & & 68 & & 32 & & 102 \\
\hline 34 & M.C. & 49 & $\mathrm{~F}$ & 4 & 4 & $1.06 / 0.96$ & & 69 & & 31 & & 97 \\
\hline 35 & M.T. & 50 & $\mathrm{~F}$ & 4 & 4 & 1. $96 / 1.41$ & & 54 & & 46 & & 89 \\
\hline 36 & M.O. & 53 & $\mathrm{~F}$ & 4 & 4 & $3.57 / 3.27$ & & 57 & & 43 & & 91 \\
\hline 37 & Y.S. & 59 & $\mathrm{~F}$ & 4 & 4 & $3.72 / 3.20$ & 46 & & 18 & 36 & & 89 \\
\hline 38 & T.N. & 53 & $\mathrm{~F}$ & $\begin{array}{l}\text { (Malig } \\
\text { RA }\end{array}$ & $\begin{array}{l}\text { gnant } \\
\text { A) }\end{array}$ & $3.10 / 2.05$ & 38 & & 21 & 21 & $20(8)$ & 75 \\
\hline
\end{tabular}

* Expressed as mg/day of hexosamine and hexuronic acid. $\uparrow$ Expressed as percent distribution in total. $\ddagger$ Percent recovery from the crude GAG applied on Separax. $\S$ Bands 1+2. // Name of the other bands. 


$\begin{array}{cccc}\text { TABLE 2. Excretion of urinary } & \text { GAG, in terms of hexosamine and } \\ & \text { hexuronic acid, from the patients with RA } & \text { with stage } \\ \text { Stage } & \text { Number of Cases } & \text { HexN (mg/day) } & \text { UA (mg/day) } \\ & & 4.47^{*} & 4.32^{*} \\ 1 & 2 & 4.34 \pm 1.96 \dagger & 3.79 \pm 1.45^{\dagger} \\ 2 & 8 & 3.13 \pm 1.29 & 2.63 \pm 1.01 \\ 3 & 15 & 2.95 \pm 1.29 & 2.59 \pm 1.15 \\ 4 & 11 & & \\ * & \text { Mean values. } \dagger \text { Standard deviation. }\end{array}$

et al. 1958) of all these cases were definite or classical. Stage and class of these cases defined by the classification of Steinbrocker et al. (1949) are described in Table 1. As shown in Table 1, 7 cases gave irregular bands. Of 38 cases, 23 cases showed abnormal excretion patterns of urinary GAG as compared with the normal range of percent distribution of bands 1, 2 and 3 (Nagatsuka et al. 1980). In these cases, the proportion of band 1 tended to increase, whereas the opposite was the case in bands 2 and 3 . This finding suggested that the metabolic rates of chondroitin sulfates tended to elevate in these cases.

The amounts of urinary GAG from the patients with RA in the earlier stages (stages 1 and 2) were larger than those in the later stages (stages 3 and 4) (Table 2), suggesting that GAG in RA were more actively metabolized in the former than in the latter. However, the proportion of bands 1,2 and 3 of stages $1+2(n=8)$ was $55.0 \pm 8.37,15.5 \pm 4.93$ and $29.5 \pm 4.10$, respectively, while that of stages $3+4(n=$ $20)$ was $53.9 \pm 7.39,18.4 \pm 4.95$ and $27.6 \pm 4.57$, respectively. This observation suggests that the proportion of the relative metabolic rates of chondroitin sulfates, dermatan sulfate and heparan sulfate in RA does not change significantly throughout the stages.

Although several investigators (Di Ferrante 1957; Loewi 1959; Wessler 1967; Ishikawa 1970) reported an increase of urinary GAG in RA, no significant increase of urinary GAG was found in the present cases of RA as compared with normal cases (Ohkawa et al. 1972).

\section{Excretion pattern of urinary GAG from the patients with malignant bone tumor}

The cases examined are listed in Table 3. Five cases gave irregular bands, and 8 cases showed abnormal excretion patterns of GAG as compared with the normal range of percent distribution of the regular three bands (Nagatsuka et al. 1980).

Case 4 of osteosarcoma excreted a large amount of urinary GAG and gave an irregular band. The data suggested elevation of the metabolic rates of GAG and acidic glycoprotein in this patient, although certain disorder in renal function could not be excluded. Alteration of the proportions of the regular bands of Case 7 of chondrosarcoma was the most prominent among 13 cases. Judging from the data, conspicuous elevation of the metabolic rates of chondroitin sulfates and a significant depression of that of dermatan sulfate were conceivable in this patient. In addition, the presence of band 5 suggested an abnormal metabolism of acidic 
TABLE 3. Excretion pattern of urinary GAG from the patients with malignant bone tumor

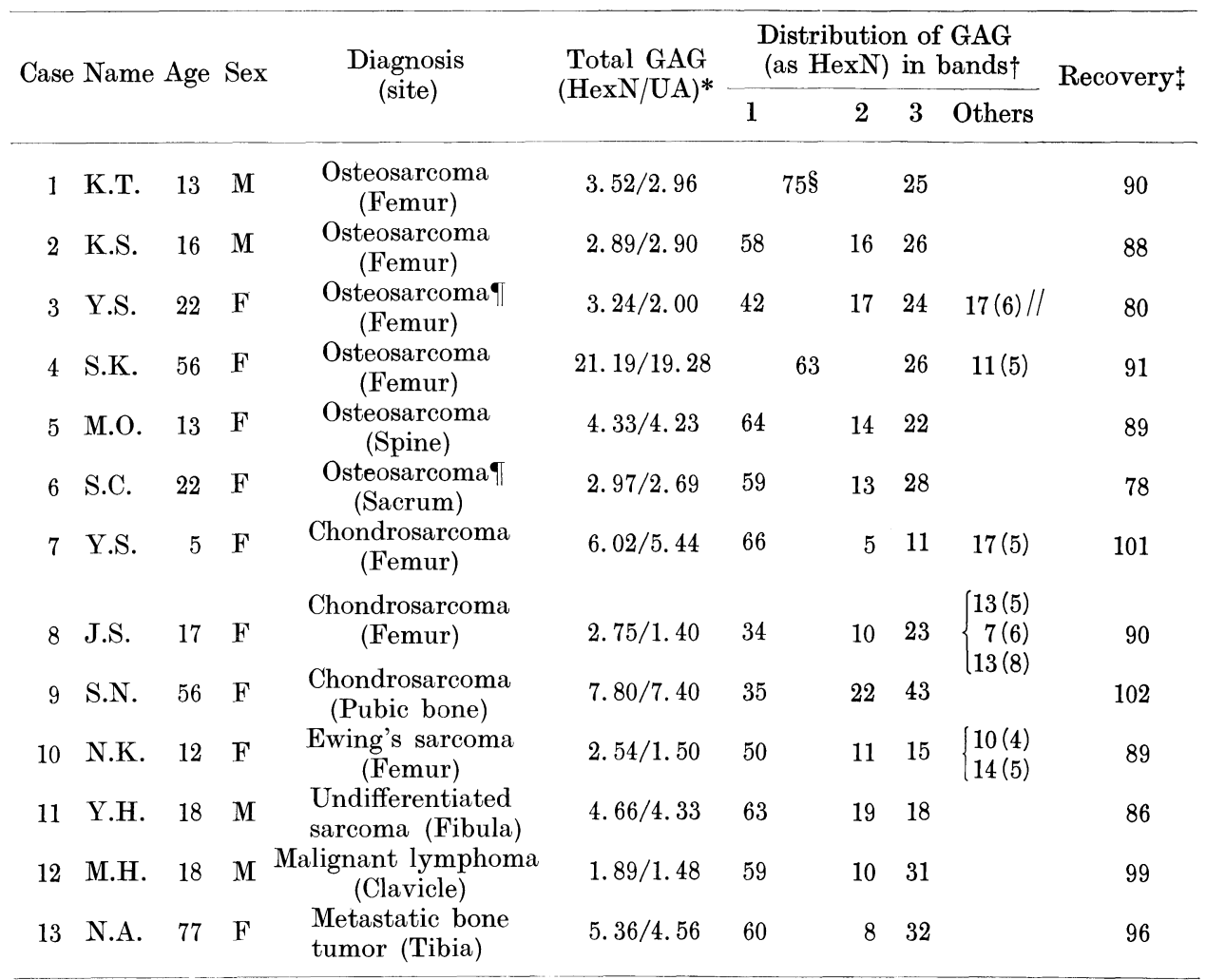

$*, \dagger, \ddagger, \S$, // See Table 1. ๆLung metastasis was observed.

glycoprotein in this patient. On the other hand, the proportion of band 3 of Case 9 of chondrosarcoma was relatively higher than those of others. Therefore, an elevation of the metabolic rate of heparan sulfate might be conceivable in this patient. This patient had wide invasion of the tumor into the surrounding tissues.

Excretion pattern of urinary GAG from the patients with benign bone tumor

The cases examined are listed in Table 4. Three cases gave irregular bands. Of 12 cases, 11 cases showed abnormal excretion patterns of urinary GAG different from the normal range of percent distribution of the regular three bands (Nagatsuka et al. 1980). In these cases, the proportion of band 1 increased and that of band 2 decreased, suggesting elevation of the metabolic rates of chondroitin sulfates and a depression of that of dermatan sulfate.

Excretion pattern of urinary GAG from the patients with bone metabolic and connective tissue diseases

The cases examined are listed in Table 5. Three cases gave irregular bands and 16 cases showed abnormal excretion patterns of urinary GAG as compared with 
TABLE 4. Excretion pattern of urinary GAG from the patients with benign bone tumor

\begin{tabular}{|c|c|c|c|c|c|c|c|c|c|c|}
\hline \multirow[t]{2}{*}{ Case } & \multirow[t]{2}{*}{ Name } & \multirow{2}{*}{\multicolumn{2}{|c|}{ Age Sex }} & \multirow{2}{*}{$\begin{array}{l}\text { Diagnosis } \\
\text { (Site) }\end{array}$} & \multirow{2}{*}{$\begin{array}{l}\text { Total GAG } \\
(\operatorname{HexN} / \mathrm{UA})^{*}\end{array}$} & \multicolumn{4}{|c|}{$\begin{array}{l}\text { Distribution of GAG } \\
\text { (as HexN) in bands } \dagger\end{array}$} & \multirow[t]{2}{*}{ Recovery $\ddagger$} \\
\hline & & & & & & 1 & 2 & 3 & Others & \\
\hline 1 & S.T. & 33 & M & $\begin{array}{l}\text { Giant cell tumor } \\
\text { (Femur) }\end{array}$ & $3.50 / 3.30$ & 47 & 15 & 38 & & 93 \\
\hline 2 & K.H. & 22 & $\mathrm{~F}$ & $\begin{array}{l}\text { Giant cell tumor } \\
\text { (Femur) }\end{array}$ & $4.38 / 4.14$ & 43 & 8 & 33 & $16(5) / /$ & 99 \\
\hline 3 & K.O. & 23 & $\mathrm{~F}$ & $\begin{array}{l}\text { Giant cell tumor } \\
\text { (Femur) }\end{array}$ & $1.80 / 1.50$ & 62 & 11 & 27 & & 101 \\
\hline 4 & M.S. & 36 & M & $\begin{array}{l}\text { Giant cell tumor } \\
\text { (Femur) }\end{array}$ & $3.03 / 2.90$ & 49 & 12 & 39 & & 95 \\
\hline 5 & S.Y. & 18 & M & $\begin{array}{l}\text { Osteoid osteoma } \\
\text { (Tibia) }\end{array}$ & $5.63 / 5.27$ & 55 & 9 & 26 & $10(6)$ & 91 \\
\hline 6 & T.O. & 49 & M & $\begin{array}{l}\text { Osteoid osteoma } \\
\text { (Tibia) }\end{array}$ & $4.23 / 3.10$ & 50 & 10 & 28 & $\left\{\begin{array}{l}3(4) \\
9(7)\end{array}\right.$ & 88 \\
\hline 7 & S.A. & 16 & M & $\begin{array}{l}\text { Bone cyst } \\
\text { (Femur) }\end{array}$ & $5.30 / 4.10$ & 52 & 23 & 25 & & 85 \\
\hline 8 & K.C. & 38 & M & $\begin{array}{l}\text { Bone cyst } \\
\text { (Femur) }\end{array}$ & $3.80 / 2.65$ & 53 & 18 & 29 & & 90 \\
\hline 9 & Y.M. & 9 & $\mathrm{M}$ & $\begin{array}{l}\text { Fibrous dysplasia } \\
\text { (Femur, Tibia) }\end{array}$ & $1.76 / 1.73$ & 58 & 17 & 25 & & 85 \\
\hline 10 & C.S. & 7 & $\mathbf{F}$ & $\begin{array}{c}\text { Fibrous dysplasia } \\
\text { (Tibia) }\end{array}$ & $2.83 / 2.81$ & $88 \S$ & & 12 & & 98 \\
\hline 11 & T.U. & 20 & F & $\begin{array}{l}\text { Metaphyseal cortical } \\
\text { defect (Tibia) }\end{array}$ & $5.77 / 5.25$ & 58 & 16 & 26 & & 97 \\
\hline 12 & A.K. & 13 & $\mathrm{~F}$ & $\begin{array}{l}\text { Multiple cartilagenous } \\
\text { exostosis }\end{array}$ & $8.33 / 8.07$ & 70 & 14 & 16 & & 89 \\
\hline
\end{tabular}

the normal range of percent distribution of the regular three bands (Nagatsuka et al. 1980). Of these cases, following cases are worthy of being noted.

Paget's disease and related one. Cases 10,11 and 12 were Paget's disease and related one. A large amount of GAG was excreted into urine of Case 10. The proportion of band 1 of Cases 10 and 12 exceeded $80 \%$ and those of bands 2 and 3 decreased remarkably. However, the proportion of band 2 to band 3 in these cases were similar to those in the normal cases (Nagatsuka et al. 1980). These observations suggested marked elevation of the metabolic rates of chondroitin sulfates in these cases. Similar excretion pattern of urinary GAG was found in Case 5 of juvenile osteoporosis.

Werner's syndrome. We reported previously an abnormal excretion of hyaluronic acid into urine of the patients with Werner's syndrome (Tokunaga et al. 1975). Of two cases of Werner's syndrome in the present study, two irregular bands were observed in Case 13, in which band 4 corresponded to that of hyaluronic acid. However, no irregular band was found in Case 14, although the proportion of band 1 increased and that of band 2 decreased. These observations suggest various abnormalities may exist in the metabolism of GAG in the patients with Werner's syndrome. 
TABLE 5. Excretion pattern of urinary GAG from the patients with bone metabolic and connective tissue diseases

\begin{tabular}{|c|c|c|c|c|c|c|c|c|c|c|c|}
\hline \multirow[t]{2}{*}{ Case } & \multirow[t]{2}{*}{ Name } & \multirow[t]{2}{*}{ Age } & \multirow[t]{2}{*}{ Sex } & \multirow[t]{2}{*}{ Diagnosis } & \multirow{2}{*}{$\begin{array}{l}\text { Total GAG } \\
(\operatorname{HexN} / \mathrm{UA})^{*}\end{array}$} & \multicolumn{5}{|c|}{$\begin{array}{l}\text { Distribution of GAG } \\
\text { (as HexN) in bands } \dagger\end{array}$} & \multirow{2}{*}{ Recovery ${ }_{\dagger}^{\dagger}$} \\
\hline & & & & & & 1 & & 2 & 3 & Others & \\
\hline 1 & T.T. & 54 & $\mathrm{~F}$ & Osteoporosis & $4.26 / 3.86$ & 48 & & 19 & 34 & \multirow{9}{*}{$26(5) / /$} & 91 \\
\hline 2 & Y.M. & 60 & $\mathrm{~F}$ & Osteoporosis & $2.81 / 2.48$ & 47 & & 15 & 38 & & 89 \\
\hline 3 & T.S. & 62 & F & Osteoporosis & 5. 80/N.D. & 47 & & 23 & 30 & & 95 \\
\hline 4 & M.T. & 12 & $\mathrm{M}$ & Juvenile osteoporosis & $5.25 / 5.08$ & \multicolumn{3}{|c|}{$89 \S$} & 11 & & 76 \\
\hline 5 & K.A. & 12 & F & Juvenile osteoporosis & 8.16/N.D. & 87 & & 4 & 9 & & 82 \\
\hline 6 & M.Y. & 33 & M & $\begin{array}{l}\text { Hypogonadal } \\
\text { osteoporosis }\end{array}$ & $4.90 / 4.67$ & 42 & & 7 & 25 & & 89 \\
\hline 7 & K.S. & 43 & $\mathrm{~F}$ & Cushing osteoporosis & 3.40/N.D. & 56 & & 22 & 22 & & 99 \\
\hline 8 & T.S. & 12 & $\mathrm{M}$ & $\begin{array}{l}\text { Juvenile rheumatoid } \\
\text { arthritis }\end{array}$ & $6.55 / 6.06$ & \multicolumn{3}{|c|}{87} & 13 & & 93 \\
\hline 9 & M.C. & 14 & $\mathrm{~F}$ & $\begin{array}{l}\text { Juvenile rheumatoid } \\
\text { arthritis }\end{array}$ & $5.81 / 5.30$ & 46 & & 11 & 43 & & 99 \\
\hline 10 & K.O. & 14 & M & $\begin{array}{l}\text { Juvenile Paget's } \\
\text { disease }\end{array}$ & 17. $43 / 15.89$ & 81 & & 7 & 12 & & 80 \\
\hline 11 & K.K. & 33 & M & $\begin{array}{l}\text { Paget's disease with } \\
\text { osteosarcoma }\end{array}$ & $3.76 / 3.76$ & 53 & & 19 & 28 & & 98 \\
\hline 12 & A.Y. & 21 & $\mathrm{~F}$ & Hyperphosphatasis & 4. $20 / 3.64$ & 83 & & 7 & 10 & & 88 \\
\hline 13 & C.M. & 44 & M & Werner's syndrome & $3.97^{* *} / 3.20^{* *}$ & 41 & & 13 & 20 & $\left\{\begin{array}{l}16(4) \\
11(6)\end{array}\right.$ & 76 \\
\hline 14 & C.S. & 32 & $\mathrm{~F}$ & Werner's syndrome & $4.27 / 3.93$ & 57 & & 13 & 30 & & 92 \\
\hline 15 & T.S. & 8 & $\mathrm{M}$ & Stickler's syndrome & $2.47 / 2.04$ & & 63 & & 37 & & 89 \\
\hline 16 & E.I. & 14 & $\mathrm{M}$ & Osteopathia striata & 7.50/N.D. & 61 & & 20 & 19 & & 101 \\
\hline 17 & H.W. & 27 & M & Achondroplasia & $4.90 / 4.40$ & & 80 & & 20 & & 98 \\
\hline 18 & T.T. & 31 & M I & Melorheostosis & $2.35 / 1.87$ & & 67 & & 33 & & 78 \\
\hline 19 & S.K. & 54 & M & Osteomalacia & $3.32 / 2.73$ & 38 & & 26 & 36 & & 89 \\
\hline 20 & S.M. & 8 & F 1 & $\begin{array}{l}\text { Mucopolysac- } \\
\text { charidosis I-S }\end{array}$ & $16.97 / 15.07$ & 18 & & 61 & 21 & & 96 \\
\hline 21 & Y.T. & 14 & $\mathrm{~F}$ & $\begin{array}{l}\text { A syndrome of } \\
\text { progressive muscle } \\
\text { spasm }\end{array}$ & $1.71 / 1.48$ & 44 & & 26 & 30 & & 91 \\
\hline 22 & T.A. & 21 & $\mathrm{~F}$ & $\begin{array}{l}\text { Osteogenesis } \\
\text { inperfecta }\end{array}$ & 1.25/N.D. & 50 & & 6 & 16 & $18(6)$ & 105 \\
\hline 23 & M.T. & 28 & $\mathrm{~F}$ & $\begin{array}{l}\text { Multiple epiphyseal } \\
\text { dysplasia }\end{array}$ & $2.20 / 1.82$ & 49 & & 20 & 31 & & 80 \\
\hline 24 & N.S. & 50 & M & Unknown & 3. $78^{* *} / 3.19 * *$ & 44 & & 21 & 35 & & 97 \\
\hline 25 & Y.O. & 50 & $\mathrm{~F}$ & Unknown & $2.05 / 1.76$ & 41 & & 18 & 41 & & 91 \\
\hline
\end{tabular}

$*, \dagger, \ddagger, \S, / /$ See Table 1. qNot determined.

** Expressed as $\mathrm{mg} / \mathrm{liter}$.

Mucopolysaccharidosis I-S (Scheie syndrome). Since clinical observations on Case 20 suggested a mucopolysaccharidosis, she was studied comprehensively. A large amount of urinary GAG was found. Since the proportion of band 2 was $61 \%$, the metabolic disorder of dermatan sulfate was conceivable in this patient. Electrophoretograms of urinary GAG of Case 20 before and after digestion with chondroitinases $\mathrm{ABC}$ and $\mathrm{AC}-\mathrm{II}$ are shown in Fig. 1. Although bands 1 and 2 disappeared after digestion with chondroitinase $\mathrm{ABC}$, band 2 remained after digestion with chondroitinase AC-II. The digestion products were examined by paper chromatography according to the procedures of Saito et al. (1968) and Suzuki et al. 


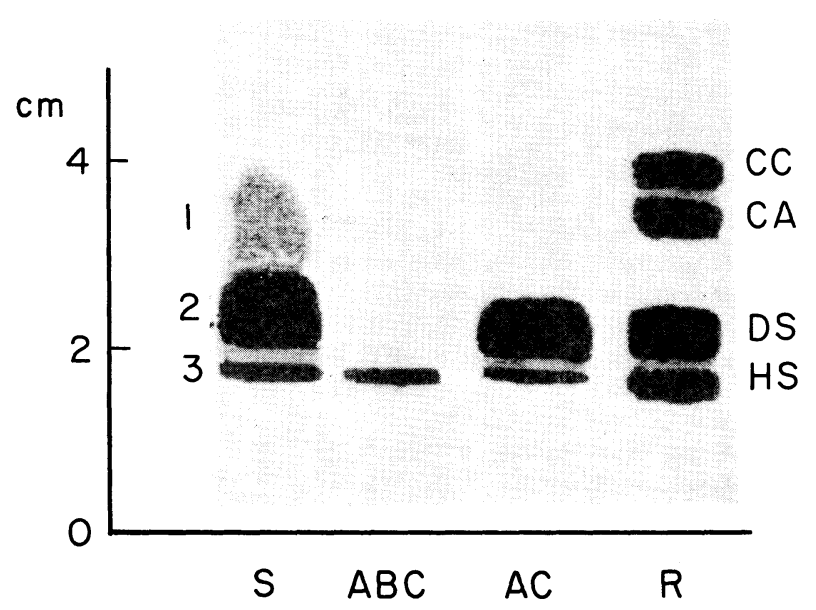

Fig. 1. Electrophoretograms of urinary GAG of Case 20 (S.M.) in Table 5 before and after digestion with chondroitinase $\mathrm{ABC}$ and chondroitinase AC-II. Electrophoresis was carried out on Separax in $0.2 \mathrm{M}$ aqueous calcium acetate at $0.5 \mathrm{~mA} / \mathrm{cm}$ for $4.5 \mathrm{hr}$. GAG were stained with Toluidine blue. ABC, Digest of chondroitinase ABC; AC, digest of chondroitinase AC-II; R, references; CC, chondroitin sulfate C; CA, chondroitin sulfate A; DS, dermatan sulfate; HS, heparan sulfate; 1 , band $1 ; 2$, band $2 ; 3$, band 3 .

(1968), using $n$-butanol-0.5 M ammonia $(5: 3, \mathrm{v} / \mathrm{v})$ solvent for $48 \mathrm{hr}$ at $25^{\circ} \mathrm{C}$. The substances were located by staining with alkaline-silver reagent. The results indicated the presence of $\triangle \mathrm{Di}-4 \mathrm{~S}$ as the major unsaturated disaccharide together with $\triangle \mathrm{Di}-6 \mathrm{~S}$ and $\triangle \mathrm{Di}-0 \mathrm{~S}$ as very scanty ones in the digest with chondroitinase ABC, while very small amounts of $\triangle \mathrm{Di}-6 \mathrm{~S}$ and $\triangle \mathrm{Di}-0 \mathrm{~S}$ were only detected in the digest with chondroitinase AC-II (data not shown). These observations indicated that this patient excreted a large amount of dermatan sulfate into urine. Consequently, the deficiency of an enzyme involved in the degradation of dermatan sulfate was conceivable in this patient. Therefore, the activity of $\alpha$-L-iduronidase in urine of this patient was assayed.

An enzyme solution was prepared by the method of Isemura et al. (1978) as follows: A portion $(200 \mathrm{ml})$ of fresh urine collected from this patient was made to $70 \%$ saturation with ammonium sulfate at $4^{\circ} \mathrm{C}$. The precipitate was collected after standing overnight at $4^{\circ} \mathrm{C}$, and dissolved in $0.9 \%$ sodium chloride. Some insoluble matter was removed by centrifugation, and the protein was reprecipitated with ammonium sulfate as above. The precipitate was dissolved in $0.9 \%$ sodium chloride, and dialyzed against $0.1 \mathrm{M}$ sodium acetate buffer $(\mathrm{pH} 4.5)$ containing $0.9 \%$ sodium chloride. The non-dialyzable fraction was used as an enzyme solution. As a control, an enzyme solution was prepared from urine of healthy male aged 34 .

The activity of $\alpha$-L-iduronidase was determined as described in Materials and Methods. The enzyme activities thus obtained of Case 20 and the control were 8 and $250 \mathrm{nmoles}$ phenol $/ \mathrm{mg}$ protein $/ 18 \mathrm{hr}$, respectively. The low activity of $\alpha$-L-iduronidase in the urine of Case 20 supported the above conception 
of the metabolic disorder of dermatan sulfate in this patient. Moreover, relatively high level of the proportion of band 3 was also supported by the low activity of this enzyme.

Judging from the above findings together with clinical observations, the patient of Case 20 was finally diagnosed as mucopolysaccharidosis type I-S (Scheie syndrome).

Osteoarthritis (arthritis deformans). Nine cases were examined (Table 6) and 4 cases gave irregular bands. Of these cases, 3 cases gave bands 8 , suggesting abnormal metabolism of acidic glycoprotein(s) in these patients. Six cases showed abnormal excretion patterns of urinary GAG in the regular bands.

Spine diseases. Eight cases were examined and 3 cases gave irregular bands (Table 7). Six cases showed abnormal excretion patterns of urinary GAG in the regular bands. Case 6 of spondylolysis excreted a large amount of urinary GAG. Since the proportions of bands 2 and 3 were 6 and $61 \%$, respectively, a

TABLE 6. Excretion pattern of urinary GAG from the patients with osteoarthritis (arthritis deformans)

\begin{tabular}{|c|c|c|c|c|c|c|c|c|c|c|}
\hline \multirow[t]{2}{*}{ Case } & \multirow[t]{2}{*}{ Name } & \multirow[t]{2}{*}{ Age } & \multirow[t]{2}{*}{$\operatorname{Sex}$} & \multirow[t]{2}{*}{ Site } & \multirow{2}{*}{$\begin{array}{l}\text { Total GAG } \\
(\text { HexN/UA)* }\end{array}$} & \multicolumn{4}{|c|}{$\begin{array}{l}\text { Distribution of GAG } \\
\text { (as HexN) in bands } \dagger\end{array}$} & \multirow[t]{2}{*}{ Recovery } \\
\hline & & & & & & 1 & 2 & 3 & Others & \\
\hline 1 & Т.T. & 35 & M & Hip & $5.04 / 4.40$ & 50 & 22 & 28 & \multirow{9}{*}{ 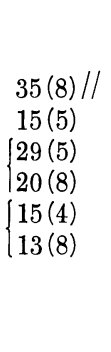 } & 95 \\
\hline 2 & S.Y. & 46 & M & Hip & 3.55/N.D. $\mid$ & 49 & 36 & 15 & & 97 \\
\hline 3 & M.S. & 30 & $\mathrm{~F}$ & Hip & $4.15 / 3.21$ & 36 & 6 & 23 & & 100 \\
\hline 4 & S.U. & 46 & $\mathrm{~F}$ & Hip & $4.56 / 3.54$ & 34 & 19 & 22 & & 91 \\
\hline 5 & M.K. & 57 & $\mathrm{~F}$ & Hip & $5.10 / 3.79$ & 25 & 9 & 16 & & 81 \\
\hline 6 & M.O. & 57 & $\mathrm{~F}$ & Hip & $6.62 / 4.40$ & 41 & 14 & 18 & & 75 \\
\hline 7 & K.T. & 62 & $\mathbf{F}$ & Hip & 4. $34 / 3.58$ & 62 & 13 & 25 & & 77 \\
\hline 8 & H.K. & 52 & $\mathbf{F}$ & Hip, Knee & $4.35 / 3.87$ & 56 & 17 & 27 & & 86 \\
\hline 9 & F.O. & 74 & $\mathrm{~F}$ & Knee & $3.98 / 3.23$ & 52 & 18 & 30 & & 88 \\
\hline
\end{tabular}

*, †,, , // See Table 1. TSee Table 5 .

TABLE 7. Excretion pattern of urinary GAG from the patients with spine diseases

\begin{tabular}{|c|c|c|c|c|c|c|c|c|c|c|}
\hline \multirow[t]{2}{*}{ Case } & \multirow[t]{2}{*}{ Name } & \multirow[t]{2}{*}{ Age } & \multirow[t]{2}{*}{ Sex } & \multirow[t]{2}{*}{ Diagnosis } & \multirow{2}{*}{$\begin{array}{l}\text { Total GAG } \\
(\operatorname{HexN} / \mathrm{UA})^{*}\end{array}$} & \multicolumn{4}{|c|}{$\begin{array}{l}\text { Distribution of GAG } \\
\text { (as HexN) in bands }{ }^{\dagger}\end{array}$} & \multirow{2}{*}{ Recovery +} \\
\hline & & & & & & 1 & 2 & 3 & Others & \\
\hline 1 & S.S. & 21 & M & Disc hernia & $6.21 / 5.53$ & 61 & 8 & 20 & $11(5) / /$ & 91 \\
\hline 2 & T.H. & 34 & M & Disc hernia & $5.19 / 4.50$ & 48 & 23 & 29 & & 86 \\
\hline 3 & S.S. & 46 & M & Disc hernia & $6.50 / 5.81$ & 43 & 9 & 33 & $15(5)$ & 88 \\
\hline 4 & N.E. & 36 & $\mathrm{M}$ & Spinal canal stenosis & $5.14 / 4.91$ & 57 & 8 & 35 & & 93 \\
\hline 5 & T.H. & 53 & $\mathrm{~F}$ & Spinal canal stenosis & $4.82 / 2.71$ & 43 & 17 & 40 & & 89 \\
\hline 6 & H.N. & 41 & $\mathbf{M}$ & Spondylolysis & $13.27 / 12.53$ & 33 & 6 & 61 & & 91 \\
\hline 7 & S.A. & 55 & M & $\begin{array}{l}\text { Ossification of posterior } \\
\text { longitudinal ligament }\end{array}$ & $5.88 / 3.45$ & 33 & 6 & 22 & $\left\{\begin{array}{r}9(4) \\
23(7) \\
7(8)\end{array}\right.$ & 83 \\
\hline 8 & M.S. & 60 & F & Pseudospondylolisthesis & $2.13 / 2.02$ & 45 & 18 & 37 & & 90 \\
\hline
\end{tabular}

*, $\dagger, \ddagger, / /$ See Table 1 . 
marked depression of the metabolic rate of dermatan sulfate and a conspicuous elevation of that of heparan sulfate were conceivable in this patient.

Other orthopedic diseases. The cases examined are listed in Table 8. Eight cases gave irregular bands and 14 cases showed abnormal excretion patterns of urinary GAG in the regular bands. Of these cases, the proportion of band 3 of Cases 9 and 15 was significantly higher than the normal range. Therefore, marked elevation of the metabolic rates of heparan sulfate was conceivable in these patients.

The present screening study on 123 cases of the orthopedic patients provides with a certain clue for the metabolism of GAG in the various types of orthopedic diseases. Of 123 cases, 84 cases showed abnormal excretion patterns of urinary GAG

TABLE 8. Excretion pattern of urinary GAG from the patients with other orthopedic diseases

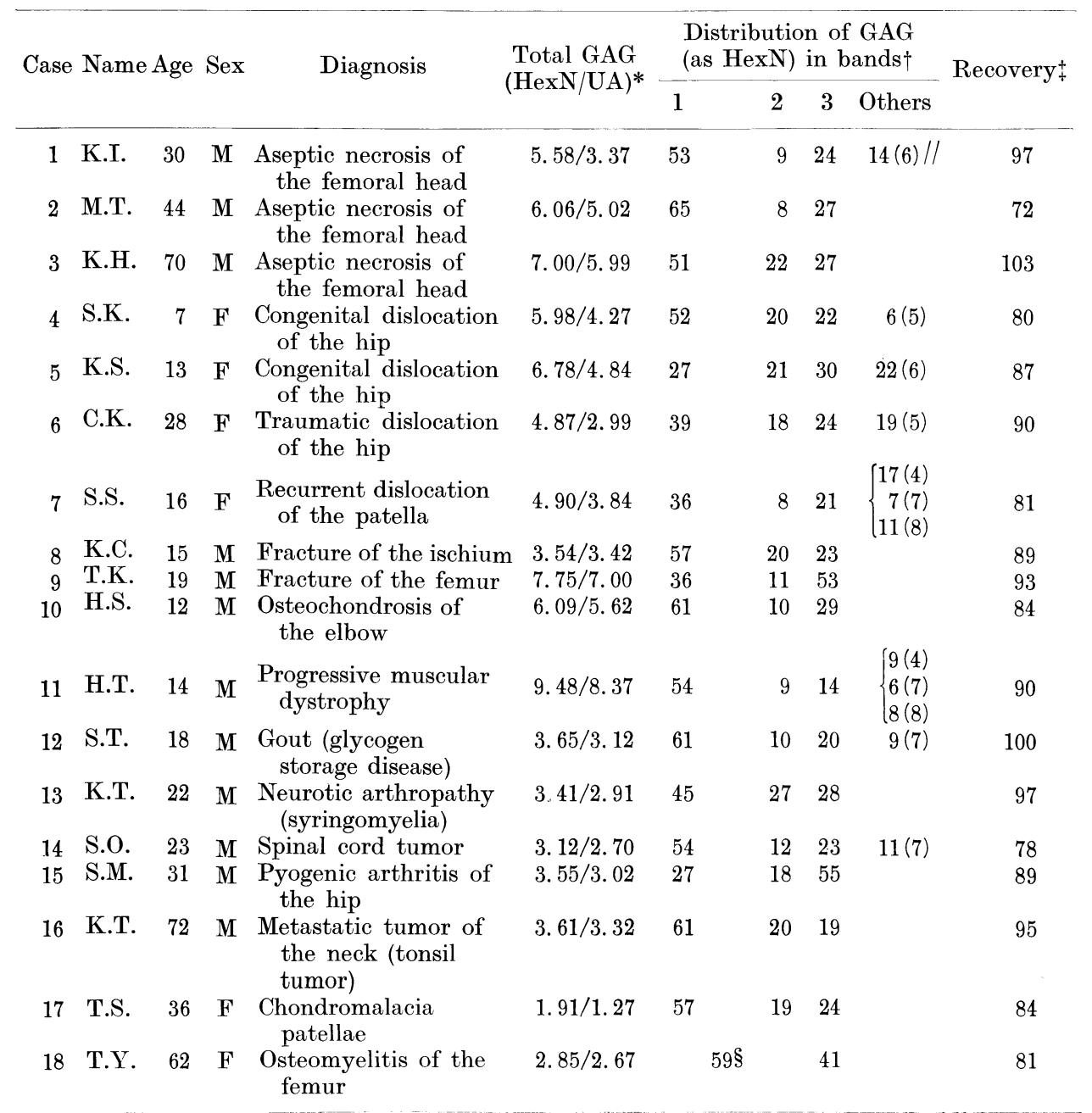

$*, \dagger, \ddagger, \S, / /$ See Table 1 . 
in the three regular bands and 33 cases gave irregular bands. The proportion of band 1 increased in 70 cases and those of bands 2 and 3 decreased in 54 and 42 cases, respectively. On the other hand, the proportion of band 1 decreased in 5 cases and those of bands 2 and 3 increased in 4 and 5 cases, respectively. Of these cases, alteration of the proportion of the regular bands was most prominent in the cases of bone metabolic and connective tissue diseases. These observations suggested therefore that the metabolic rates of chondroitin sulfates tended to elevate in orthopedic diseases. In addition, certain metabolic disorder of dermatan sulfate and heparan sulfate was suggested in several cases. The presence of irregular band(s) suggested abnormal metabolism of acidic glycoprotein(s) except for the cases at puberty (Nagatsuka et al. 1980).

Case 20 of bone metabolic and connective tissue diseases was only one studied comprehensively, since it was conceivable to be a mucopolysaccharidosis from the excretion pattern of urinary GAG and clinical observations. Enzymatic digestion of its urinary GAG with chondroitinases and assay of the activity of $\alpha$-Liduronidase in urine of this patient indicated that this case was mucopolysaccharidosis I-S (Scheie syndrome). Elucidation of the metabolic disorder of GAG in the patients with abnormal metabolic patterns of urinary GAG is a project of further study.

\section{Acknowledgments}

This work was supported by a Grant-in-Aid for Scientific Research from the Ministry of Education, Science and Culture, Japan. We thank Professor E. Wakamatsu, Department of Orthopedic Surgery, for his interest throughout this work.

\section{References}

1) Bitter, T. \& Muir, H.M. (1962) A modified uronic acid carbazole reaction. Analyt. Biochem., 4, 330-334.

2) Di Ferrante, N. (1957) Urinary excretion of acid mucopolysaccharides by patients with rheumatoid arthritis. J. clin. Invest., 36, 1516-1520.

3) Isemura, M., Kosaka, H., Ikenaka, T., Kido, R. \& Yoshimura, T. (1978) Fluorometric measurement of urinary $o$-L-iduronidase activity. J. Biochem., 84, 627-632.

4) Ishikawa, I. (1970) Urinary acid mucopolysaccharides in collagen diseases. Conn. Tiss., 2, 11-29.

5) Liem, K.O. \& Hooghwinkel, G.J.M. (1975) The use of $\alpha$-L-iduronidase activity determination in leucocytes for the detection of Hurler and Scheie syndromes. Clin. chim. Acta, 60, 259-262.

6) Loewi, G. (1959) Urinary excretion of acidic mucopolysaccharides in rheumatoid arthritis and other disease. Ann. rheum. Dis., 18, 239-243.

7) Lowry, O.H., Rosebrough, N.J., Farr, A.L. \& Randall, R.L. (1951) Protein measurement with the Folin phenol reagent. J. biol. Chem., 193, 265-275.

8) Nagatsuka, Y., Sato, K. \& Yosizawa, Z. (1980) A method of screening test for excretion pattern of urinary glycosaminoglycans and its application to normal human urine. Tohoku J. exp. Med., 132, 159-171.

9) Nagatsuka, Y., Sato, K., Satake, S. \& Yosizawa, Z. (1981) Excretion pattern of urinary glycosaminoglycans from orthopedic patients. Tohoku J. exp. Med., 133, 413-416.

10) Ohkawa, S., Hata, R., Nagai, Y. \& Sugiura, M. (1972) Urinary excretion of acidic 
glycosaminoglycans in the aged. J. Biochem., 72, 1495-1501.

11) Ropes, M.W., Bennett, G.A., Cobb, S., Jacox, R. \& Jessar, R.A. (1958) Revision of diagnostic criteria for rheumatoid arthritis. Bull. rheum. Dis., 9, 175-176.

12) Saito, H., Yamagata, T. \& Suzuki, S. (1968) Enzymatic methods for the determination of small quantities of isomeric chondroitin sulfates. J. biol. Chem., 243, 15361542.

13) Steinbrocker, O., Traeger, C.H. \& Batterman, R.C. (1949) Therapeutic criteria in rheumatoid arthritis. J. Amer. med. Ass., 140, 659-662.

14) Suzuki, S., Saito, H., Yamagata, T., Anno, K., Seno, N., Kawai, Y. \& Furuhashi, T. (1968) Formation of three types of disulfated disaccharides from chondroitin sulfates by chondroitinase digestion. J. biol. Chem., 243, 1543-1550.

15) Tokunaga, M., Futami, T., Wakamatsu, E., Endo, M. \& Yosizawa, Z. (1975) Werner's syndromes as "hyaluronuira". Clin. chim. Acta, 62, 89-96.

16) Wessler, E. (1967) Determination of acidic glycosaminoglycans (mucopolysaccharides) in urine by an ion exchange method. Clin. chim. Acta, 16, 235-243. 